Supporting information for

\title{
Establishment of Dual Hairpin Ligation Induced Isothermal Amplification for Universal, Accurate and Flexible Nucleic Acid Detection
}

\author{
Huan Li, ${ }^{\mathrm{a}, \mathrm{b}}$ Yidan Tang, ${ }^{\mathrm{a}}$ Defeng Song, ${ }^{\mathrm{c}}$ Baiyang $\mathrm{Lu},{ }^{\mathrm{a}}$ Lulu Guo, ${ }^{\mathrm{a}, \mathrm{b}}$ and Bingling $\mathrm{Li}^{* a, \mathrm{~b}}$ \\ a State Key Laboratory of Electroanalytical Chemistry, Changchun Institute of Applied Chemistry, \\ Chinese Academy of Science, Changchun, Jilin, 130022, P. R. China; \\ b Department of Chemistry, University of Science and Technology of China, Hefei, Anhui, 230026, \\ P.R. China; Tel: +86-0431-85262008; E-mail address: Binglingli@ciac.ac.cn. \\ c Department of General Surgery, China-Japan Union Hospital of JiLin University, Changchun, \\ Jilin, 130021, P.R. China. \\ Table of Contents:

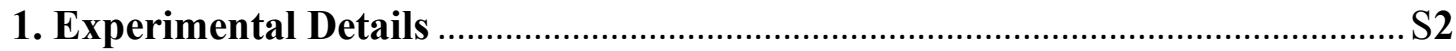

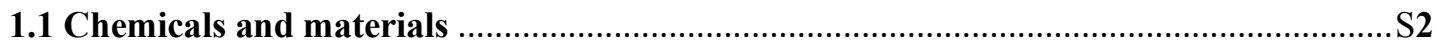

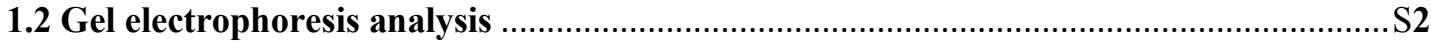 \\ 1.3 Optimization of the temperature for DHLA ...................................................................

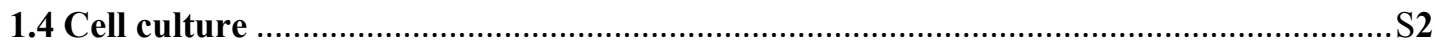 \\ 1.5 RNA extraction in cell lines and human serum blood ................................................ \\ 1.6 RT-qPCR (Reverse-transcription Real-time Quantitation PCR) .................................S3

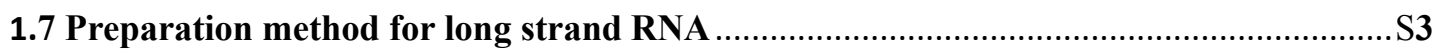

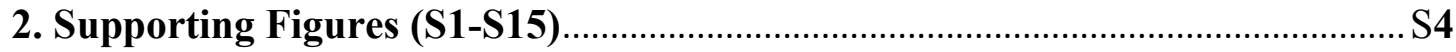

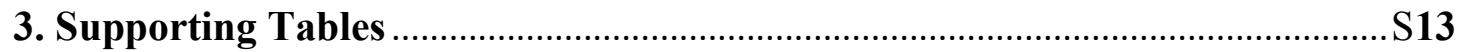

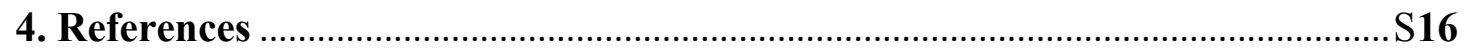




\section{EXPERIMENTAL DETAILS}

\subsection{Chemicals and materials}

MiRcute Plus miRNA First-Strand cDNA Kit, miRcute Plus miRNA qPCR Kit (SYBR Green) and RNAsimple Total RNA Kit are from Tiangen (Beijing, China). HiScribe ${ }^{\mathrm{TM}}$ T7 High Yield RNA Synthesis Kit is purchased from New England Biolabs (Ipswich, MA, USA). $2 \times$ TBE/Urea Sample Buffer and $5 \times$ Nucleic Acid Sample Buffer are available from Bio-Rad (California, USA). Dulbecco's modified Eagle's medium (DMEM), fetal bovine serum (FBS) and human recombinant insulin are supplied by Thermo Fisher Scientific (WA, USA). Penicillin and streptomycin are purchased from Solarbio (Beijing, China). SanPrep Column microRNA Extraction Kit, Acryl/Bis 40\% Solution (19:1), DiaSpin DNA Gel Extraction Kit and DNA Marker A (25-500 bp) are from Sangon Biotech Co., Ltd (Shanghai, China). All oligonucleotides are stored in $\mathrm{H}_{2} \mathrm{O}$ at $-20^{\circ} \mathrm{C}$. The concentrations of the DNA suspensions are determined by measuring the absorbance at $260 \mathrm{~nm}$ using the DeNovix DS-11+ FX spectrophotometer (DeNovix Inc., Wilmington, DE, USA). Unless otherwise indicated, all regents are of analytical grade.

\subsection{Gel electrophoresis analysis}

The hybridization process of $A_{R 9}, B_{13}$, and miRNA-21 is analyzed using $12 \%$ native PAGE. And the ligation efficiency of three pairs of $A_{R \beta 1}$ and $B_{\beta 2}$ strands which bind to target with different hybrid length is characterized by $12 \%$ denatured PAGE in $1 \times \mathrm{TBE}$ buffer at room temperature. Electrophoresis is performed at a constant voltage of $300 \mathrm{~V}$ for $90 \mathrm{~min}$ with a load of $10 \mu \mathrm{L}$ of sample with $\left[\mathrm{A}_{\mathrm{R} \beta 1}\right]=\left[\mathrm{B}_{\beta 2}\right]=300 \mathrm{nM},[$ miRNA-21] $=240 \mathrm{nM}$ in each lane. After electrophoresis, the gel is stained for 30 min with SYBR Gold diluted 5/100,000 in $1 \times$ TBE buffer and imaged under the iBright FL1000 (Invitrogen, California, USA) using 365 nm UV light.

\subsection{Optimization of the temperature for DHLA}

In order to get the best amplification temperature, the fluorescence signals are detected at $55^{\circ} \mathrm{C}$, $57^{\circ} \mathrm{C}, 59^{\circ} \mathrm{C}, 61^{\circ} \mathrm{C}, 63^{\circ} \mathrm{C}$, and $65^{\circ} \mathrm{C}$ respectively using QuantStudio 5 (ABI, California, USA). As shown in Figure S6, as the temperature increases, the POI decreases and the POI reaches the minimum at $63^{\circ} \mathrm{C}$, so $63^{\circ} \mathrm{C}$ is selected as the amplification reaction temperature of DHLA.

\subsection{Cell culture}

The two human cell lines included human breast cancer cell line (MCF-7) and human embryonic kidney cell line (HEK293T) are cultured in DMEM supplemented with 10\% FBS, 100 $\mathrm{U} / \mathrm{mL}$ penicillin, and $100 \mu \mathrm{g} / \mathrm{mL}$ streptomycin, and the medium of MCF-7 is further supplied with $0.01 \mathrm{mg} / \mathrm{mL}$ human recombinant insulin. All cells are incubated in a humidified incubator at $37^{\circ} \mathrm{C}$ with $5 \% \mathrm{CO}_{2}$.

\subsection{RNA extraction in cell lines and human serum blood}

Total RNA samples are isolated from MCF-7 and HEK293T cell line by using RNAsimple Total RNA Kit at their exponential growth stages. Human serum samples with anticoagulants is provided by the specimen bank of the China-Japan Union Hospital of JiLin University and approved by the Ethics Committee of China-Japan Union Hospital of JiLin University (Approval Number: 2019071606). MiRNAs in serum samples are extracted by using SanPrep column microRNA mini-preps kit following the recommended procedure. The total RNA and miRNA are stored at $-80^{\circ} \mathrm{C}$ for further use.

\subsection{RT-qPCR (Reverse-transcription Real-time Quantitation PCR)}


The cDNA samples are prepared using miRcute Plus miRNA First-Strand cDNA Kit. The reaction process is as follows, a total volume of $20 \mu \mathrm{L}$ solution containing $2.5 \mu \mathrm{L}$ of the extracted total RNA (382 ng/ul), $10 \mu \mathrm{L} 2 \times$ miRNA RT Reaction Buffer, $2 \mu \mathrm{L}$ miRNA RT Enzyme Mix, and $5.5 \mu \mathrm{L}$ nuclease-free water is incubated at $42^{\circ} \mathrm{C}$ for $60 \mathrm{~min}$ and $95^{\circ} \mathrm{C}$ for $3 \mathrm{~min}$ to inactivate reverse transcriptase. The cDNA samples are stored at $-20^{\circ} \mathrm{C}$ for future use. Then the qPCR is performed with miRcute Plus miRNA qPCR Kit (SYBR Green). The $50 \mu \mathrm{L}$ reaction solution contain $2 \mu \mathrm{L}$ of 10 times diluted above cDNA sample, $25 \mu \mathrm{L} 2 \times$ miRcute Plus miRNA PreMix, 1 $\mu \mathrm{L}$ Forward Primer (has-miR-21-5p and has-U6 used for miRNA-21 and U6 respectively) (10 $\mu \mathrm{M}), 1 \mu \mathrm{L}$ Reverse Primer $(10 \mu \mathrm{M})$, and $21 \mu \mathrm{L}$ nuclease-free water. The qPCR procedure is as follows: incubate at $95^{\circ} \mathrm{C}$ for $15 \mathrm{~min}$, followed by 45 cycles of $94^{\circ} \mathrm{C}$ for $20 \mathrm{~s}, 60^{\circ} \mathrm{C}$ for $34 \mathrm{~s}$ in the LightCycler ${ }^{\circledR} 96$ Real-Time PCR System.

\subsection{Preparation method for long strand RNA}

First, 2019-nCoV S full-length plasmid (Sangon, Shanghai, China) is used as the template for PCR. The PCR product is extracted by DiaSpin DNA Gel Extraction Kit. And then the product is used in the transcription reaction processed by HiScribe ${ }^{\mathrm{TM}} \mathrm{T} 7 \mathrm{High}$ Yield RNA Synthesis Kit, and synthesized RNA is purified by $8 \%$ denatured PAGE. The above S RNA is stored at $-80^{\circ} \mathrm{C}$ for later use. As for Zika RNA, except for the plasmid ${ }^{1}$ from Addgene (plasmid number: 75008), everything else is the same as S RNA. The primer sequences for PCR are shown in table S1. 


\section{Supporting Figures}
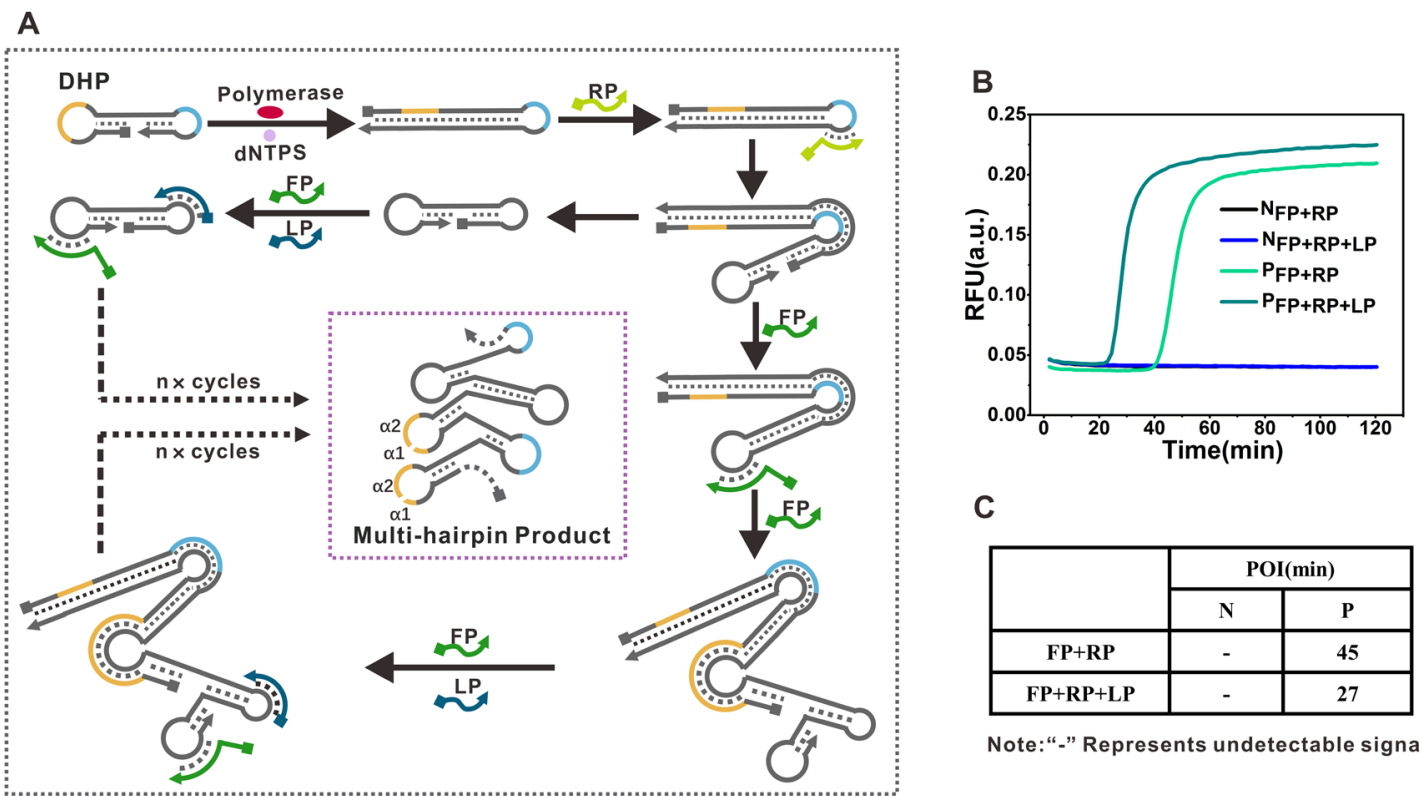

C

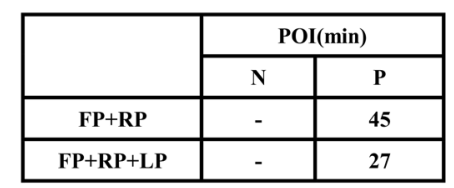

Note:“=" Represents undetectable signa

Figure S1. (A) Schematic illustration of the amplification process after adding LP to DHLA. (B) Real-time fluorescence curves and (C) Comparison table with POI values of different combinations of primers with (P) or without $(\mathrm{N}) 40 \mathrm{pM}$ miRNA-21. It shows that the addition of LP (right-loop primer) can greatly increase amplification reaction speed under the zero background. In the above figure, $[\mathrm{FP}]=[\mathrm{RP}]=0.8 \mu \mathrm{M},[\mathrm{LP}]=0.4 \mu \mathrm{M},\left[\mathrm{A}_{\text {miRNA-21 }}\right]=\left[\mathrm{B}_{\text {miRNA-21 }}\right]=640$ pM. 




Figure S2. Verification of hybridization ability among $A_{R \beta 1}, B_{\beta 2}$, and miRNA-21. Left: the scheme of strand hybridization for native PAGE; Right: the $12 \%$ native PAGE of the hybridization of $A_{R 9}$, $\mathrm{B}_{13}$, and target miRNA-21. M: DNA Marker A (25-500 bp); Lane 1: $\mathrm{A}_{\mathrm{R} 9}$; Lane 2: $\mathrm{B}_{13}$; Lane 3: miRNA-21; Lane 4: $\mathrm{B}_{13}+$ miRNA-21; Lane 5: $\mathrm{A}_{\mathrm{R} 9}+$ miRNA-21; Lane 6: $\mathrm{A}_{\mathrm{R} 9}+\mathrm{B}_{13}+$ miRNA-21; Lane 7: $A_{R 9}+B_{13}$. In the figure, $\left[A_{R 9}\right]=\left[B_{13}\right]=300 \mathrm{nM}$, [miRNA-21] $=240 \mathrm{nM}$. (Note: the strand or hybrid represented by each band is marked on the electrophoresis image.)

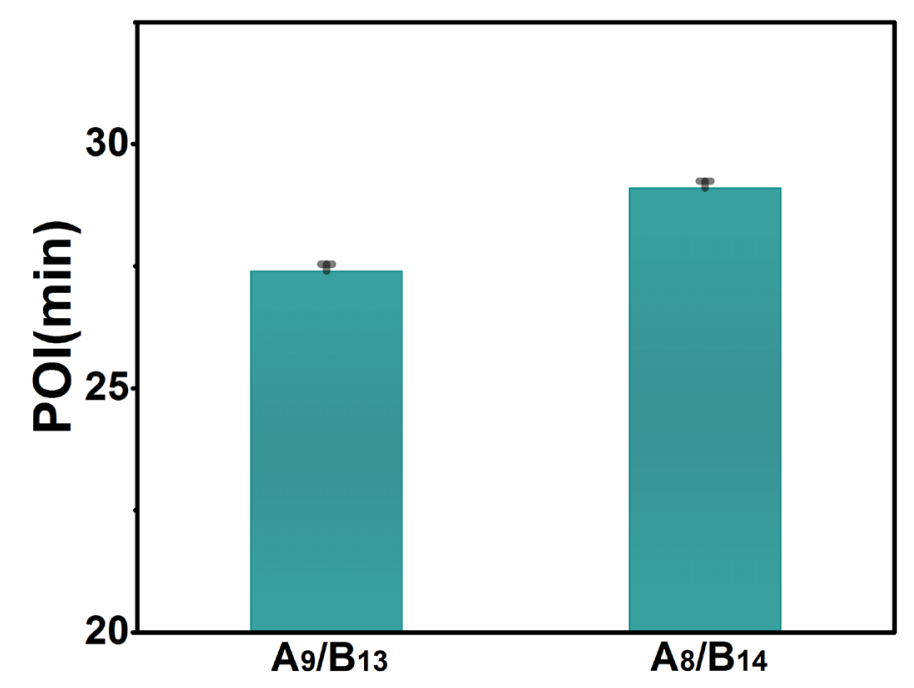

Figure S3. The POI comparison between combination $A_{8} / B_{14}$ and combination $A_{9} / B_{13}$ in the presence of $40 \mathrm{pM}$ miRNA-21. Error bars are obtained from at least three repetitive tests. In the Figure, $[\mathrm{FP}]=[\mathrm{RP}]=0.8 \mu \mathrm{M},[\mathrm{LP}]=0.4 \mu \mathrm{M},\left[\mathrm{A}_{9}\right]=\left[\mathrm{B}_{13}\right]=\left[\mathrm{A}_{8}\right]=\left[\mathrm{B}_{14}\right]=640 \mathrm{pM}$. 
A

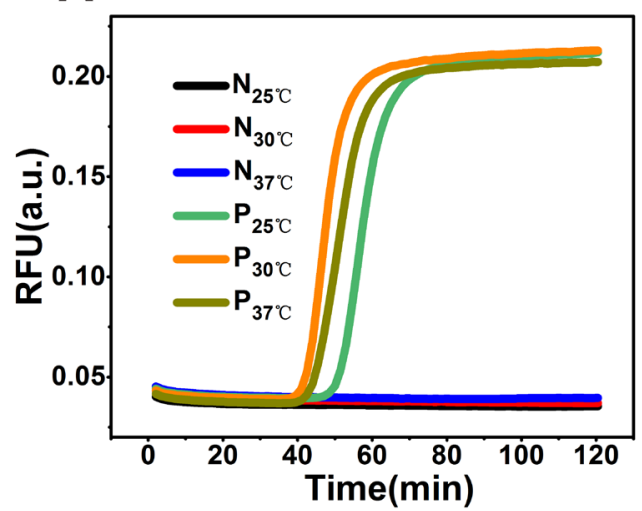

B

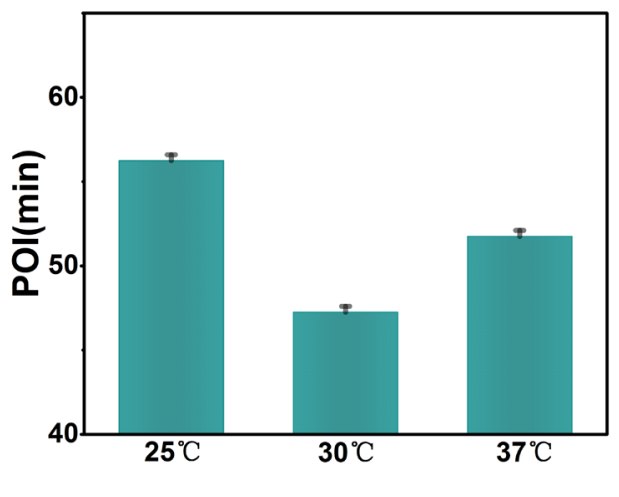

Figure S4. The optimization of ligation temperature based on SplintR ligase. (A) Real-time fluorescence curves of DHLA at different ligation temperature with (P) or without $(\mathrm{N}) 40 \mathrm{pM}$ miRNA-21. (B) Bar graph of POI at $25^{\circ} \mathrm{C}, 30^{\circ} \mathrm{C}$, and $37^{\circ} \mathrm{C}$ in the presence of $40 \mathrm{pM}$ miRNA-21. It shows that $30^{\circ} \mathrm{C}$ is the best for the ligation reaction. Error bars are obtained from at least three repetitive tests. In both Figure $\mathrm{S} 4 \mathrm{~A}$ and $\mathrm{S} 4 \mathrm{~B},[\mathrm{FP}]=[\mathrm{RP}]=0.4 \mu \mathrm{M},\left[\mathrm{A}_{\text {miRNA-21 }}\right]=\left[\mathrm{B}_{\text {miRNA-21 }}\right]=640$ pM.

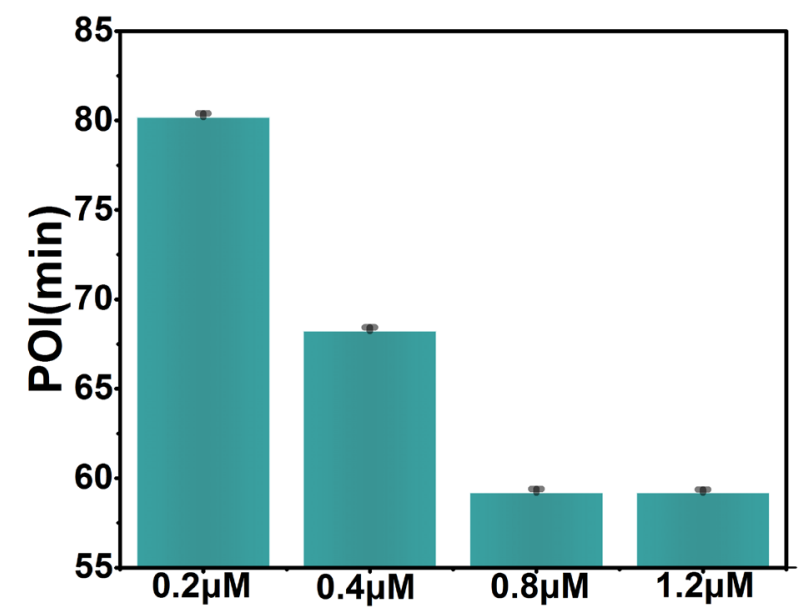

Figure S5. The optimization of primer concentration. POI bar graph of different concentrations of primers with $40 \mathrm{pM}$ miRNA-21. The primer concentration is as follows: $[\mathrm{FP}]=[\mathrm{RP}]=0.2 \mu \mathrm{M} / 0.4$ $\mu \mathrm{M} / 0.8 \mu \mathrm{M} / 1.2 \mu \mathrm{M}$. The results show that the reaction speed increases with the increase of the primer concentration, and reaches a plateau at $0.8 \mu \mathrm{M}$. Error bars are obtained from at least three repetitive tests. In the above figure, $\left[\mathrm{A}_{\text {miRNA-21 }}\right]=\left[\mathrm{B}_{\text {miRNA-21 }}\right]=640 \mathrm{pM}$. 
A

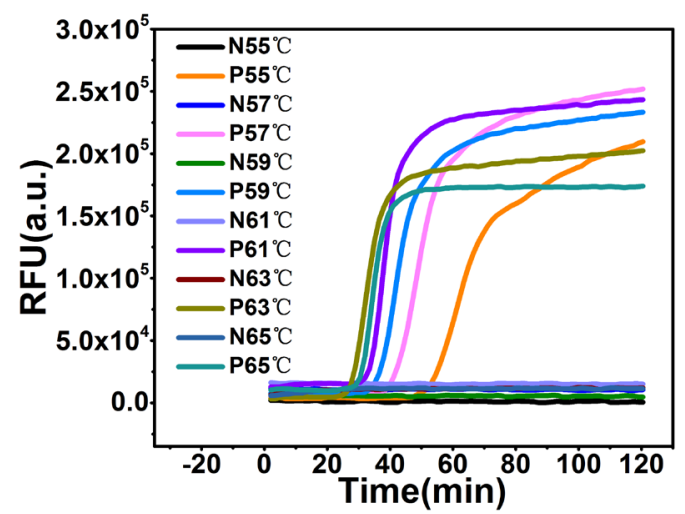

B

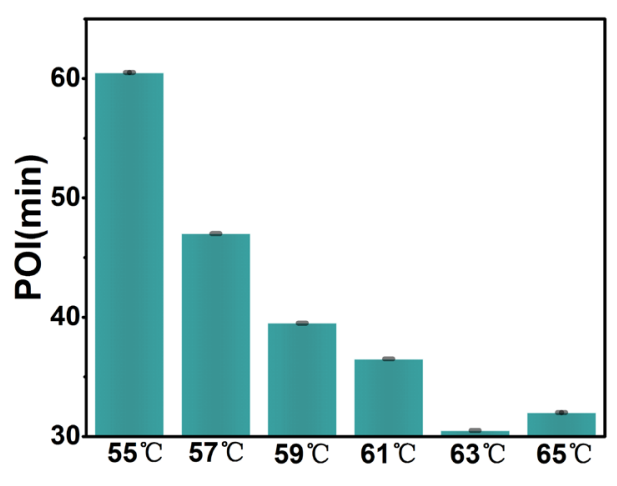

Figure S6. The optimization of amplification temperature. (A) Real-time fluorescence curves at different amplification temperature with (P) or without (N) 40 pM miRNA-21. (B) Bar graph of POI at $55^{\circ} \mathrm{C}, 57^{\circ} \mathrm{C}, 59^{\circ} \mathrm{C}, 61^{\circ} \mathrm{C}, 63^{\circ} \mathrm{C}$, and $65^{\circ} \mathrm{C}$ with $40 \mathrm{pM}$ miRNA-21. As the temperature rises, the smaller the POI, which is the smallest at $63^{\circ} \mathrm{C}$, so the amplification reaction is performed at $63^{\circ} \mathrm{C}$. Error bars are obtained from at least three repetitive tests. In both Figure S6A and S6B, $[\mathrm{FP}]=[\mathrm{RP}]=0.8 \mu \mathrm{M},[\mathrm{LP}]=0.4 \mu \mathrm{M},\left[\mathrm{A}_{\text {miRNA-21 }}\right]=\left[\mathrm{B}_{\text {miRNA-21 }}\right]=640 \mathrm{pM}$. 

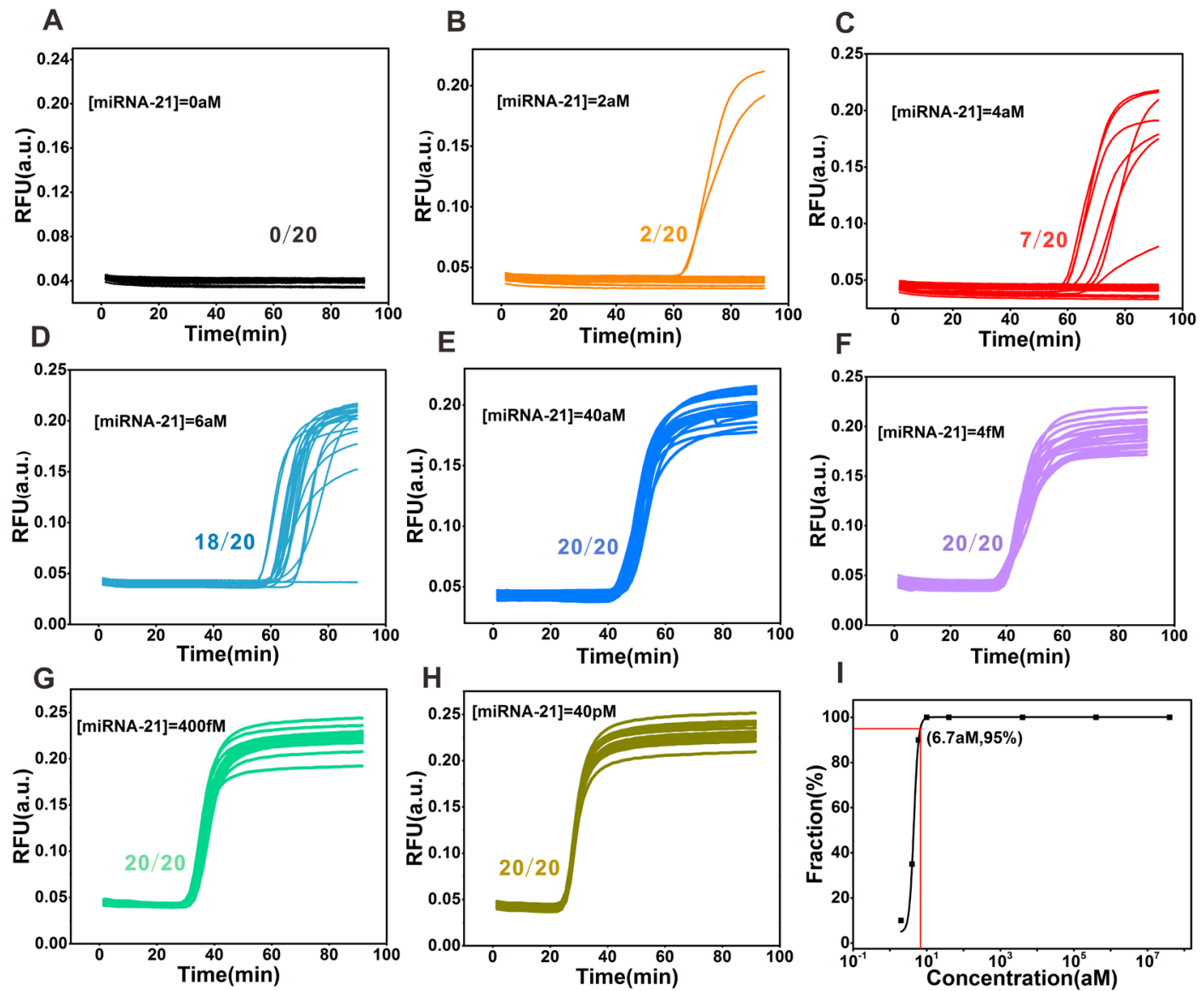

Figure S7. (A)-(H) 20 replicates with miRNA-21 concentration from 0 aM to $40 \mathrm{pM}$. The amplification ration within $90 \mathrm{~min}$ is given near real-time fluorescence curves. (I) Probit curve based on the fraction obtained from above Figure A-H for evaluating LOD. From Figure S7I, when the miRNA- 21 concentration is $6.7 \mathrm{aM}$, the amplification is observed $95 \%$ of the time. For all the Figures, $[\mathrm{FP}]=[\mathrm{RP}]=0.8 \mu \mathrm{M},[\mathrm{LP}]=0.4 \mu \mathrm{M},\left[\mathrm{A}_{\text {miRNA-21 }}\right]=\left[\mathrm{B}_{\text {miRNA-21 }}\right]=640 \mathrm{pM}$. 
A

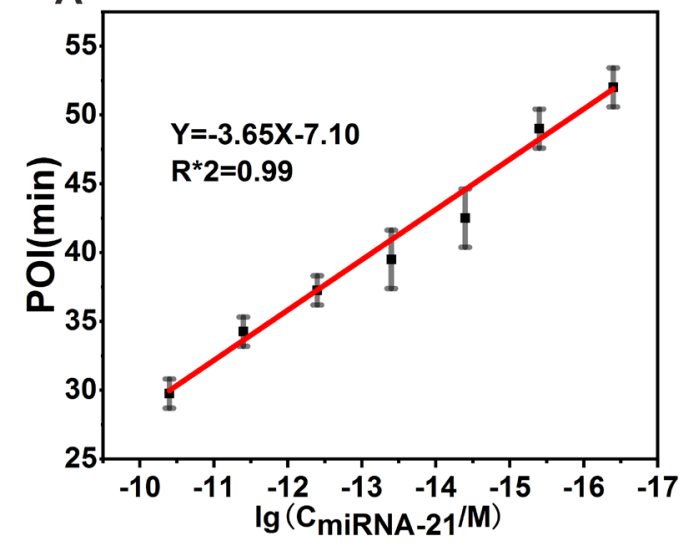

B

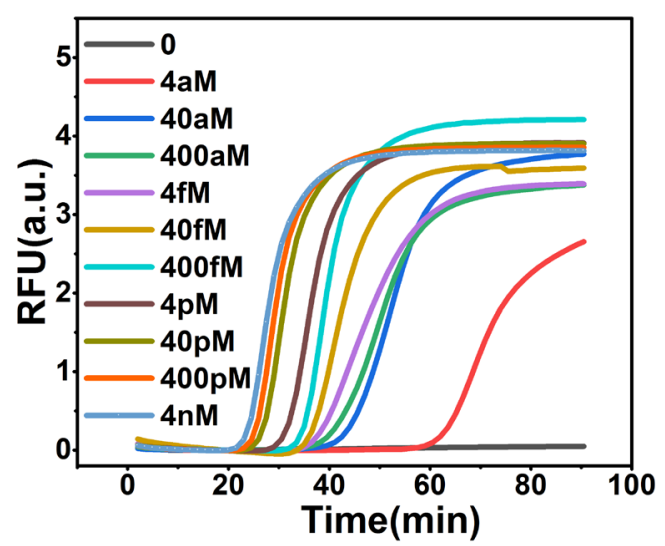

Figure S8. (A) Dependence of POI on logarithmic miRNA-21 concentration from 40 aM to 40 pM. (B) Real-time fluorescence curves of DHLA with different concentrations of the miRNA-21 from $4 \mathrm{aM}$ to $4 \mathrm{nM}$. Error bars are obtained from at least three repetitive tests. For all the Figures from S8A to $\mathrm{S} 8 \mathrm{~B},[\mathrm{FP}]=[\mathrm{RP}]=0.8 \mu \mathrm{M},[\mathrm{LP}]=0.4 \mu \mathrm{M},\left[\mathrm{A}_{\text {miRNA-21 }}\right]=\left[\mathrm{B}_{\text {miRNA-21 }}\right]=640 \mathrm{pM}$.
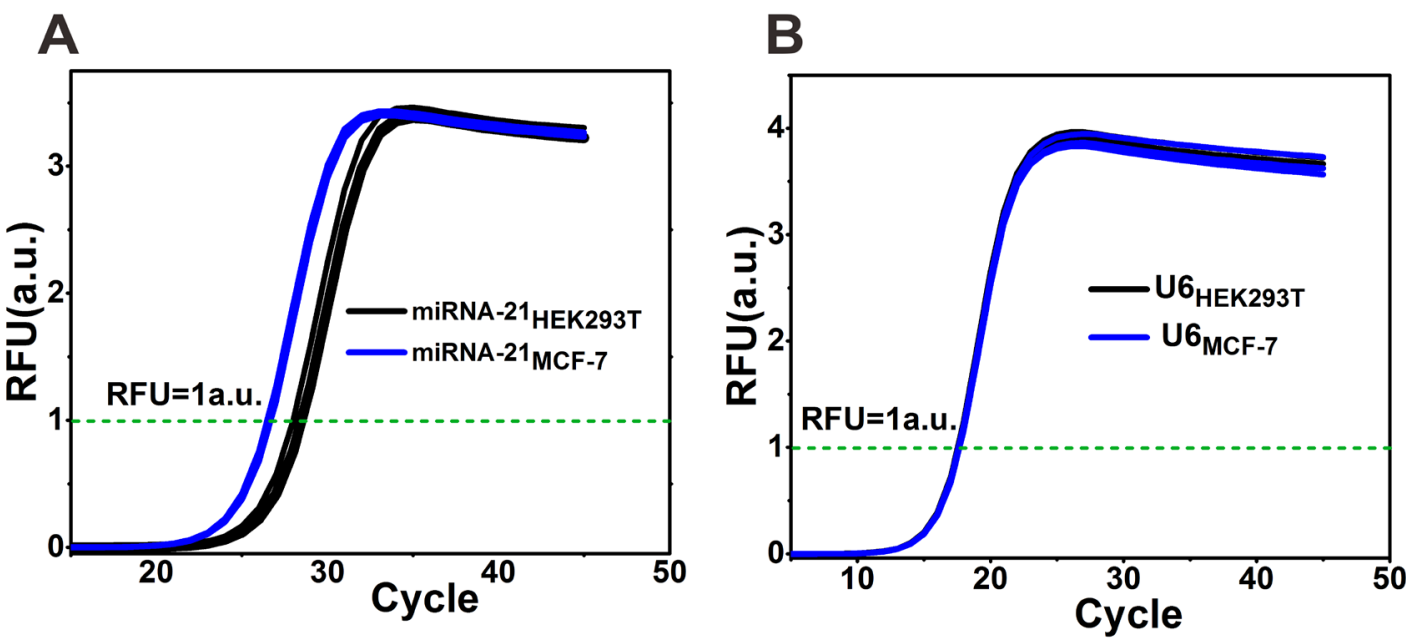

Figure S9. RT-qPCR curves for evaluating the miRNA-21 expression levels (A) and U6 RNA (internal control) expression levels (B) in total RNA extracted from MCF-7 cell lines and HEK293T cell lines, respectively. Through the threshold adjustment of LightCycler ${ }^{\circledR} 96$ Real-Time PCR System (the threshold value is at the position where RFU is 1 a.u.), the average $\mathrm{Ct}$ values of U6 RNA in HEK293T and MCF-7 are 17.56 and 17.58, while the average Ct values of miRNA-21 are 28.32 and 26.60 , respectively. It shows that MCF-7 overexpresses miRNA-21 compared to HEK293T when the expression level of the U6 RNA is similar in above cell lines. RT-qPCR are carried out using commercial kit (miRcute Plus miRNA First-Strand cDNA Kit and miRcute Plus miRNA qPCR Kit (SYBR Green) from Tiangen). 

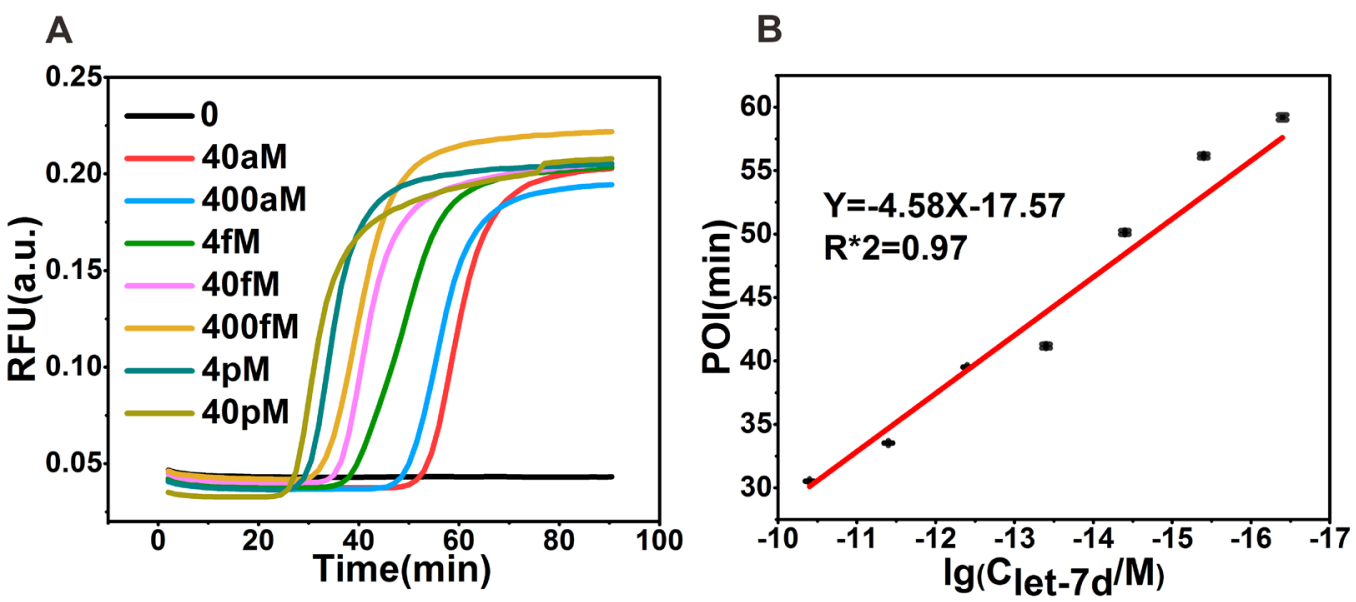

Figure S10. The versatility demonstration of DHLA. (A) Real-time fluorescence curves with different concentrations of the let-7d. (B) Dependence of POI on logarithmic let-7d concentration from $40 \mathrm{aM}$ to $40 \mathrm{pM}$. Error bars are obtained from at least three repetitive tests. In the above figure, $[\mathrm{FP}]=[\mathrm{RP}]=0.8 \mu \mathrm{M},\left[\mathrm{LP}_{\text {let-7d }}\right]=0.4 \mu \mathrm{M},\left[\mathrm{A}_{\text {let }-7 \mathrm{~d}}\right]=\left[\mathrm{B}_{\text {let }-7 \mathrm{~d}}\right]=640 \mathrm{pM}$.
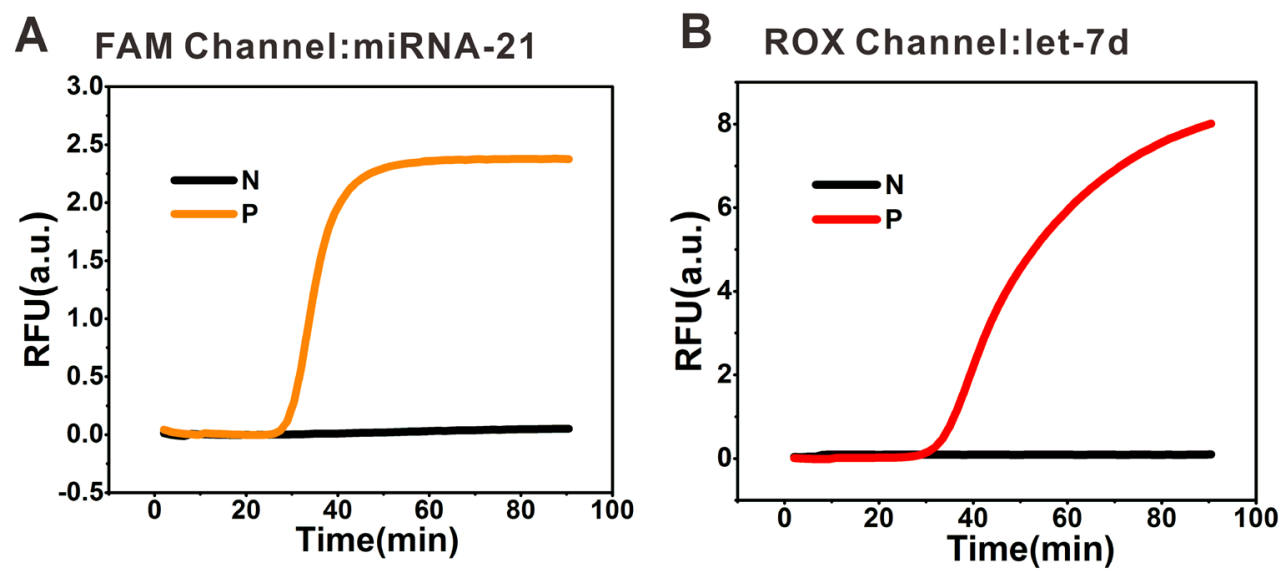

Figure S11. A) Real-time fluorescence curves in FAM channel with $(\mathrm{P})$ and without $(\mathrm{N})$ miRNA-21. B) Real-time fluorescence curves in ROX channel with (P) and without $(\mathrm{N})$ let-7d. 


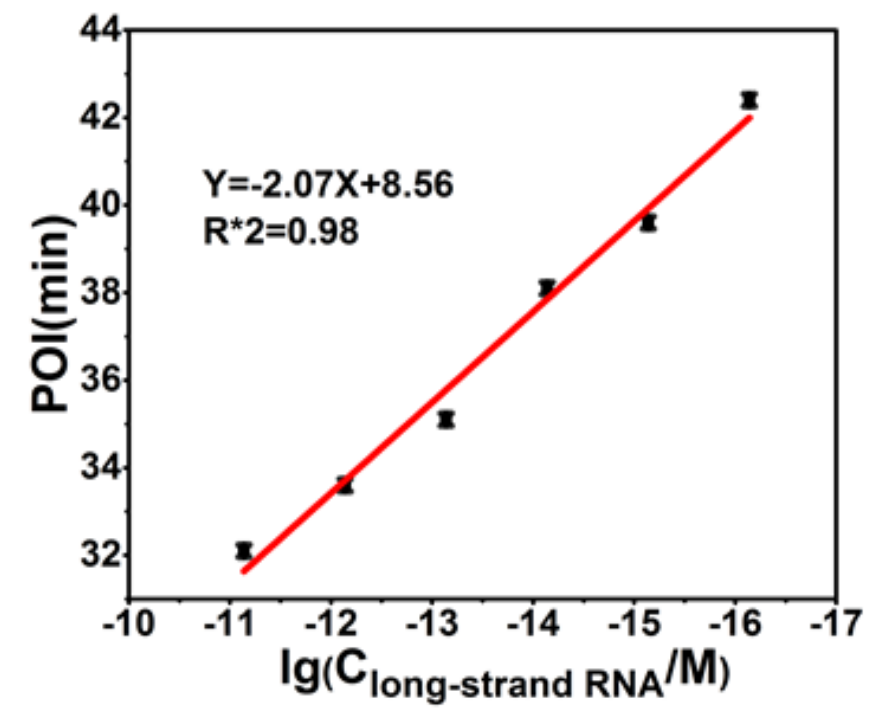

Figure S12. Dependence of POI on logarithmic Long-Strand RNA concentration using the mixture of $\mathrm{SHP}_{\mathrm{T} 1}, \mathrm{SHP}_{\mathrm{T} 2}$, and $\mathrm{SHP}_{\mathrm{T} 3}$. Error bars are obtained from at least three repetitive tests.

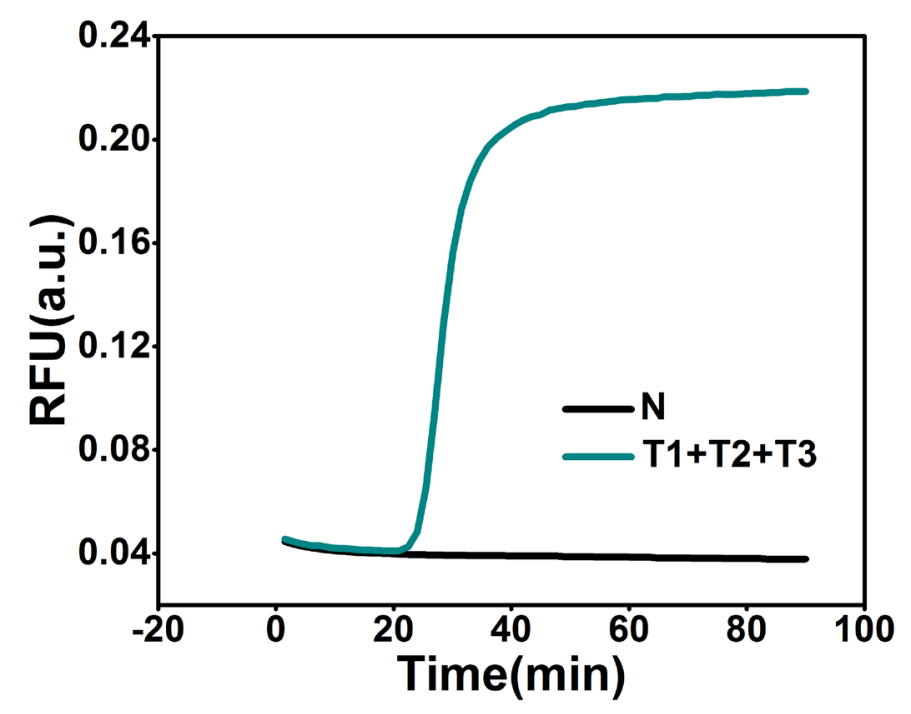

Figure S13. Real-time fluorescence curves of DHLA with $(\mathrm{T} 1+\mathrm{T} 2+\mathrm{T} 3)$ and without $(\mathrm{N})$ synthetic $\mathrm{T} 1, \mathrm{~T} 2$, and $\mathrm{T} 3$ fragment combinations in the presence of $\mathrm{SHP}_{\mathrm{T} 1}, \mathrm{SHP}_{\mathrm{T} 2}$, and $\mathrm{SHP}_{\mathrm{T} 3}$. 


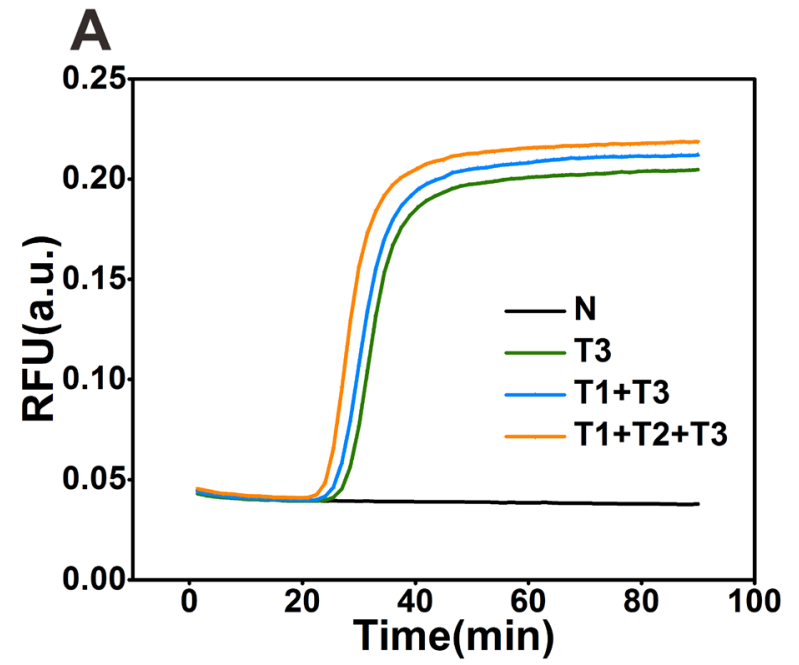

B

\begin{tabular}{|l|l|l|}
\hline & Target name & POI(min) \\
\hline Single Target & T1 & 30 \\
\cline { 2 - 3 } & T2 & 31.5 \\
\cline { 2 - 3 } & T3 & 31.5 \\
\hline Two Targets & T1+T2 & 28.5 \\
\cline { 2 - 3 } & T1+T3 & 30 \\
\cline { 2 - 3 } & T2+T3 & 28.5 \\
\hline Three Targets & T1+T2+T3 & 27 \\
\hline
\end{tabular}

Figure S14. (A) Real-time fluorescence curves of DHLA with and without $(\mathrm{N})$ different synthetic $\mathrm{T}$ fragment combinations in the presence of $\mathrm{SHP}_{\mathrm{T} 1}, \mathrm{SHP}_{\mathrm{T} 2}$, and $\mathrm{SHP}_{\mathrm{T} 3}$. (B) The POI comparison with different $\mathrm{T}$ fragment combinations using the mixture of $\mathrm{SHP}_{\mathrm{T} 1}, \mathrm{SHP}_{\mathrm{T} 2}$, and $\mathrm{SHP}_{\mathrm{T} 3}$.

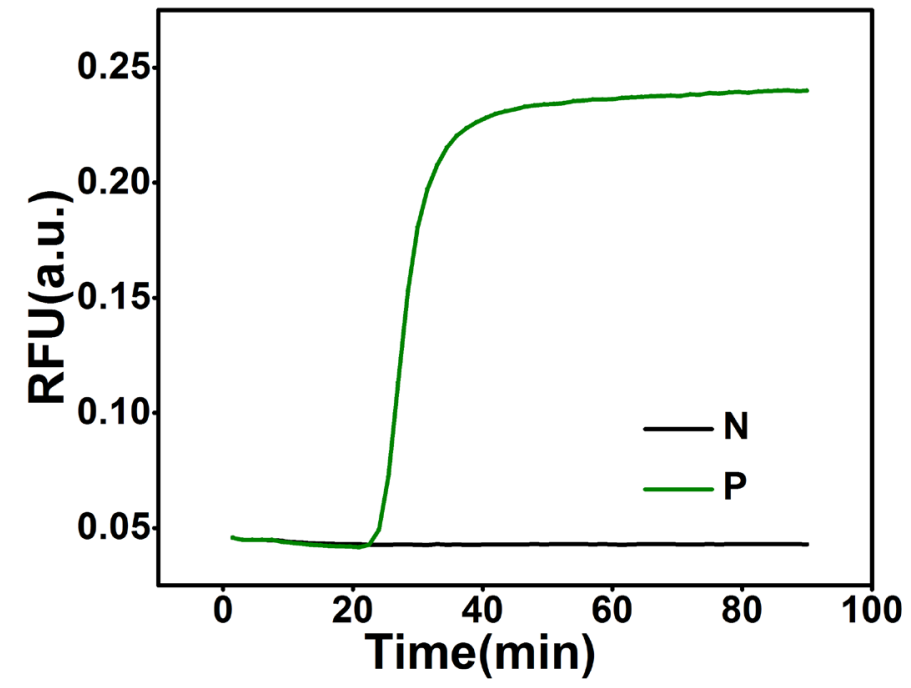

Figure S15. Real-time fluorescence curves with (P) or without (N) 40 pM Long-Strand RNA-2 in the presence of SHP $\mathrm{T}_{\mathrm{T}}$. 


\section{Supporting Tables}

Table S1. Oligonucleotides used in this paper

\begin{tabular}{|c|c|c|}
\hline Name & Sequences(from $5^{\prime}$ to $3^{\prime}$ ) & \\
\hline$A_{R 9}$ & GGGCTTGCCGGGTTTGATCAGTCAACATCA & \multirow[t]{5}{*}{ Figure $1 \mathrm{~B}, \mathrm{~S} 2$} \\
\hline$A_{R 11}$ & GGGCTTGCCGGGTTTGATCAGTCAACATCAGT & \\
\hline$A_{R 13}$ & GGGCTTGCCGGGTTTGATCAGTCAACATCAGTCT & \\
\hline $\mathrm{B}_{9}$ & $\begin{array}{l}\text { (P)GATAAGCTAATCGTCTCGGCTAGTGCATTGATCAAACCCGGCAAGCC } \\
\text { C }\end{array}$ & \\
\hline $\mathrm{B}_{11}$ & $\begin{array}{l}\text { (P)CTGATAAGCTAATCGTCTCGGCTAGTGCATTGATCAAACCCGGCAAG } \\
\text { CCC }\end{array}$ & \\
\hline miRNA-21 & UAGCUUAUCAGACUGAUGUUGA & $\begin{array}{l}\text { Figure } 1,2,4 B, \\
\text { S1-S8 }\end{array}$ \\
\hline $\mathrm{B}_{\text {miRNA-21 }}\left(\mathrm{B}_{13}\right)$ & $\begin{array}{l}\text { (P)GTCTGATAAGCTAATCGTCTCGGCTAGTGCATTGATCAAACCCGGCA } \\
\text { AGCCC }\end{array}$ & $\begin{array}{l}\text { Figure } 1,2,3 \mathrm{~A}, 4 \mathrm{~B}, \\
\text { S1-S8 }\end{array}$ \\
\hline$A_{\text {miRnA-21 }}\left(A_{9}\right)$ & $\begin{array}{l}\text { GTCCATCGAGGATGTCGAGTTGCCGCAGTACTGGTAGAGGCGGCGATG } \\
\text { GTTGAACCAGTCGACCCAGCGCGCGAACTCGACATCCTCGATGGACCG } \\
\text { CCAGGGCTTGCCGGGTTTGATCAGTCAACATCA }\end{array}$ & $\begin{array}{l}\text { Figure } 1 \mathrm{C}, 2,3 \mathrm{~A}, 4 \mathrm{~B}, \\
\mathrm{~S} 1, \mathrm{~S} 3-\mathrm{S} 8\end{array}$ \\
\hline$A_{8}$ & $\begin{array}{l}\text { GTCCATCGAGGATGTCGAGTTGCCGCAGTACTGGTAGAGGCGGCGATG } \\
\text { GTTGAACCAGTCGACCCAGCGCGCGAACTCGACATCCTCGATGGACCG } \\
\text { CCAGGGCTTGCCGGGTTTGATCAGTCAACATC }\end{array}$ & Figure $1 \mathrm{C}$ \\
\hline $\mathrm{B}_{14}$ & $\begin{array}{l}\text { (P)AGTCTGATAAGCTAATCGTCTCGGCTAGTGCATTGATCAAACCCGGC } \\
\text { AAGCCC }\end{array}$ & Figure $1 \mathrm{C}$ \\
\hline FP & GGGCTTGCCGGGTTTGATCAATGCACTAGCCGAGAC & Figure $1 \mathrm{C}, 2-5, \mathrm{~S} 1$, \\
\hline $\mathrm{RP}$ & GTCCATCGAGGATGTCGAGTTGCCGCAGTACTGGTAGAGG & S3-S8, S10-S15 \\
\hline SD-Q & TGAACCAGTCGACCCAGCGCG(BHQ1) & \\
\hline SD-F & (FAM)CGCGCTGGGTCGACTGGTTCAACCATCGCCG & $\begin{array}{l}\text { Figure } 1 \mathrm{C}, 2,3,4 \mathrm{~B}, \\
5, \quad \mathrm{~S} 1, \quad \mathrm{~S} 3-\mathrm{S} 8, \\
\mathrm{~S} 10-\mathrm{S} 11 \mathrm{~A}, \mathrm{~S} 12-\mathrm{S} 15\end{array}$ \\
\hline LP & CAGTCAACATCAGTCTGA & $\begin{array}{l}\text { Figure } 1 \mathrm{C}, 2,3 \mathrm{~A}, 4 \mathrm{~B} \text {, } \\
\mathrm{S} 1, \mathrm{~S} 3, \mathrm{~S} 6-\mathrm{S} 8\end{array}$ \\
\hline
\end{tabular}




\begin{tabular}{|c|c|c|}
\hline miRNA-141 & UAACACUGUCUGGUAAAGAUGG & \multirow{4}{*}{ Figure $2 \mathrm{~B}$} \\
\hline let-7d & AGAGGUAGUAGGUUGCAUAGUU & \\
\hline miRNA-200b & UAAUACUGCCUGGUAAUGAUGA & \\
\hline miRNA-429 & UAAUACUGUCUGGUAAAACCGU & \\
\hline miRNA-21-M 1 & UAGCUUAUCAGACAGAUGUUGA & \multirow[t]{3}{*}{ Figure $2 \mathrm{C}$} \\
\hline miRNA-21-M 2 & UAGCUUAUCAGAGUGAUGUUGA & \\
\hline miRNA-21-M & UAGCUUAUCAGAEAUGAUGUUGA & \\
\hline$A_{\text {Let-7d }}$ & $\begin{array}{l}\text { GTCCATCGAGGATGTCGAGTTGCCGCAGTACTGGTAGAGGCGGCGATG } \\
\text { GTTGAACCAGTCGACCCAGCGCGCGAACTCGACATCCTCGATGGACCG } \\
\text { CCAGGGCTTGCCGGGTTTGATCAGAACTATGCA }\end{array}$ & Figure $3 \mathrm{C}, \mathrm{S} 10$ \\
\hline$B_{\text {Let-7d }}$ & $\begin{array}{l}\text { (P)ACCTACTACCTCTATCGTCTCGGCTAGTGCATTGATCAAACCCGGCAA } \\
\text { GCCC }\end{array}$ & Figure $3 \mathrm{C}, \mathrm{S} 10, \mathrm{~S} 11 \mathrm{~B}$ \\
\hline$L P_{\text {Let-7d }}$ & CAGAACTATGCAACCTAC & Figure $3 \mathrm{C}, \mathrm{S} 10, \mathrm{~S} 11 \mathrm{~B}$ \\
\hline \multicolumn{3}{|c|}{ Multi-target multi-channel detection } \\
\hline$A_{\text {miRNA-10b }}$ & $\begin{array}{l}\text { GTCCATCGAGGATGTCGAGTTGCCGCAGTACTGGTAGAGGCTCGCGCA } \\
\text { CGTGAACCAGTCGACCCAGCGCGCGAACTCGACATCCTCGATGGACCG } \\
\text { CCAGGGCTTGCCGGGTTTGATCAGCACAAATTCG }\end{array}$ & \multirow[t]{4}{*}{ Figure $4 \mathrm{C}$} \\
\hline$B_{\text {miRNA-10b }}$ & $\begin{array}{l}\text { (P)GTTCTACAGGGTAATCGTCTCGGCTAGTGCATTGATCAAACCCGGC } \\
\text { AAGCCC }\end{array}$ & \\
\hline miRNA-10b & UACCCUGUAGAACCGAAUUUGUG & \\
\hline$L P_{\text {miRNA-10b }}$ & CAGCACAAATTCGGTTCT & \\
\hline$A_{\text {Let-7d-R }}$ & $\begin{array}{l}\text { GTCCATCGAGGATGTCGAGTTGCCGCAGTACTGGTAGAGGCTCGCGCA } \\
\text { CGTGAACCAGTCGACCCAGCGCGCGAACTCGACATCCTCGATGGACCG } \\
\text { CCAGGGCTTGCCGGGTTTGATCAGAACTATGCA }\end{array}$ & Figure S11B \\
\hline SD-R & (ROX)CGCGCTGGGTCGACTGGTTCACGTGCGCGAG & Figure $4 \mathrm{C}, \mathrm{S} 11 \mathrm{~B}$ \\
\hline \multicolumn{3}{|c|}{ Multiple probe OR gate analysis } \\
\hline$A_{T 1}$ & $\begin{array}{l}\text { GTCCATCGAGGATGTCGAGTTGCCGCAGTACTGGTAGAGGCGGCGAT } \\
\text { GGTTGAACCAGTCGACCCAGCGCGCGAACTCGACATCCTCGATGGACC } \\
\text { GCCAGGGCTTGCCGGGTTTGATCAGGGATCTGAA }\end{array}$ & $\begin{array}{l}\text { Figure } \quad 5 C-5 \mathrm{I}, \\
\text { S12-S15 }\end{array}$ \\
\hline
\end{tabular}




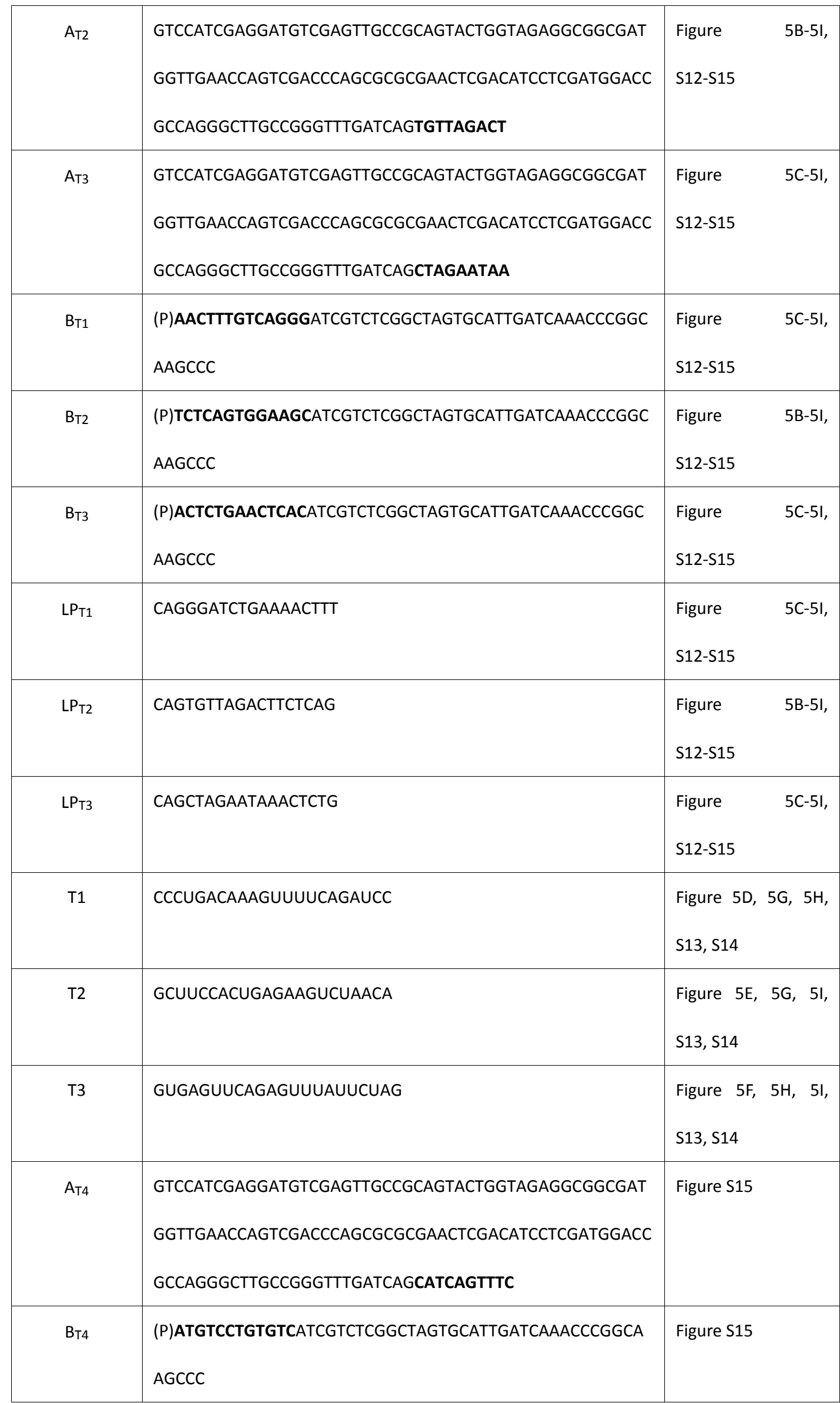




\begin{tabular}{|c|l|l|}
\hline LPT4 $_{\text {S }}$ & CAGCATCAGTTTCATGTC & Figure S15 \\
\hline SFP & TAATACGACTCACTATAGGGGATGTTTTGTTTTTCTTG & \multirow{2}{*}{ Figure 5B, 5C, S12 } \\
\hline SRP & TTATGTGTAATGTAATTTGACTCCTTTGAGCACTGGC & \\
\hline ZikaFP & CGGTGATGTCGGCGATATAGGCTT & \multirow{2}{*}{ Figure S15 } \\
\hline ZikaRP & TTGACAGCTTATCATCGATAAGCTTTAAT & \\
\hline
\end{tabular}

Note: The letter $\mathrm{P}$ indicates the $\mathrm{PO}_{4}$ modification at the 5 ' end. The bold region is complementary sequence of the target. The underlined base is mutation site of miRNA-21.

\section{References}

[1] Pardee, K.; Green, A. A.; Takahashi, M. K.; Braff, D.; Lambert, G.; Lee, J. W.; Ferrante, T.; Ma, D.; Donghia, N.; Fan, M.; Daringer, N. M.; Bosch, I.; Dudley, D. M.; O'Connor, D. H.; Gehrke, L.; Collins, J. J. Rapid, Low-Cost Detection of Zika Virus Using Programmable Biomolecular Components. Cell 2016, 165, 1255-1266. 